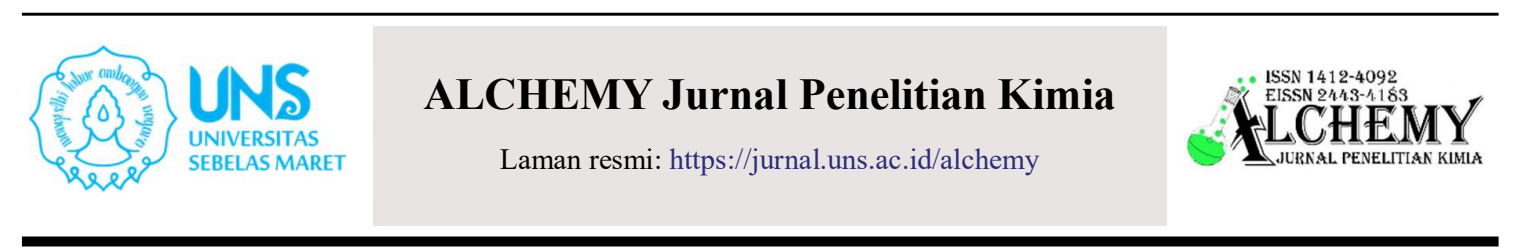

\title{
Kompetisi Fenol pada Limbah Buatan Menggunakan Kopoli-Eugenol Divinil Benzena $10 \%$ sebagai Senyawa Pembawa
}

\author{
Agung Abadi Kiswandono*, Sonny Widiarto, Dessy Tiara Elvia Nita Sari, R. Supriyanto, \\ Hardoko Insan Qudus, Rinawati Rinawati, Anisa Rahmawati, Wahyu Devariani \\ Jurusan Kimia, FMIPA, Universitas Lampung \\ Jalan Prof. Sumantri Brojonegoro No. 1 Bandar Lampung 35141 Indonesia \\ ${ }^{*}$ Corresponding author: agung.abadi@fmipa.unila.ac.id \\ DOI: 10.20961/alchemy.18.1.45356.1-9
}

Received 02 November 2020, Accepted 26 August 2021, Published 01 March 2022

\begin{abstract}
Kata kunci:
ABSTRAK. Salah satu komponen yang bertanggung jawab terhadap pemisahan pada metode Polymer Co-EDVB;

fenol; Inclusion Membrane (PIM) adalah senyawa pembawa. Senyawa pembawa pada pemisahan fenol sangat diperlukan dalam rangka ikut menyelamatkan lingkungan perairan. Penelitian ini menyintesis senyawa pembawa, yaitu kopoli-eugenol divinil benzena (co-EDVB) 10\%. Senyawa ini merupakan hasil sintesis Membran Polimer Inklusi. antara eugenol dan divinil benzena dengan teknik polimerisasi menggunakan katalis triflourodietil eter $\left(\mathrm{BF}_{3} \mathrm{O}\left(\mathrm{C}_{2} \mathrm{H}_{5}\right)_{2}\right)$. Senyawa pembawa selanjutnya dipakai sebagai salah satu komponen pembentuk membran PIM. Membran PIM yang terbentuk kemudian diaplikasikan untuk uji pemisahan fenol pada limbah buatan, yaitu limbah yang dibuat dengan mencampurkan fenol, logam $\mathrm{Pb}$ (II) dan $\mathrm{Cu}(\mathrm{II})$. Senyawa hasil sintesis dikarakterisasi menggunakan Fourier Transform Infrared (FTIR), sedangkan membran PIM sebelum dan setelah transpor fenol dikarakterisasi menggunakan FTIR dan Scanning Electron Microscope (SEM). Hasil penelitian didapatkan bahwa senyawa co-EDVB 10\% telah berhasil disintesis, ditandai dengan hilangnya serapan spektra IR gugus vinil pada bilangan gelombang $995,27 \mathrm{~cm}^{-1}$ dan serapan gugus alil pada bilangan gelombang $1636,5 \mathrm{~cm}^{-1}$. Hasil penelitian juga menunjukkan bahwa transpor fenol menggunakan membran PIM dipengaruhi oleh kehadiran logam berat. Persentase transpor fenol pada kontrol didapatkan sebesar $48,8 \%$, sedangkan pada limbah buatan didapatkan $27,25 \%$.
\end{abstract}

Keywords:

Co-EDVB;

phenol;

Polymer Inclusion

Membrane.

\begin{abstract}
Competition of Phenol in Artificial Waste using Copoly-Eugenol Divinyl Benzene $10 \%$ as Carrier Compound. One of the components responsible for the separation in the Polymer Inclusion Membrane (PIM) method is a carrier compound. Carrier compounds in the separation of phenol are very necessary in order to save the aquatic environment. This study synthesized a carrier compound namely copoly-eugenol divinyl benzene (co-EDVB) $10 \%$. This compound was synthesized between eugenol and benzene divinyl with polymerization techniques using the catalyst triflourodietil ether $\left(\mathrm{BF}_{3} \mathrm{O}\left(\mathrm{C}_{2} \mathrm{H}_{5}\right)_{2}\right)$. Furthermore, the carrier compound was used as one of the components of PIM membrane formation. The formed PIM was is applied to test the separation of phenols in artificial waste made by mixing phenols, metal $\mathrm{Pb}(\mathrm{II})$, and $\mathrm{Cu}(\mathrm{II})$. The synthesized compounds were characterized using Fourier Transform Infrared (FTIR), whereas PIM membranes before and after phenol transport were characterised using FTIR and Scanning Electron Microscope (SEM). The results show that the co-EDVB10\% compound was successfully synthesized indicated by the loss of the IR absorption spectra of the vinyl group at a wavenumber of $995.27 \mathrm{~cm}^{-1}$ and the absorption of the allyl group at a wavenumber of 1636.5 $\mathrm{cm}^{-1}$. Moreover, the results show that phenol transport using PIM membranes was influenced by the presence of heavy metals. The percentage of phenol transport in the control was $48.8 \%$, while in the artificial waste was $27.25 \%$.
\end{abstract}

\section{PENDAHULUAN}

Penggunaan fenol yang luas di bidang industri akan berdampak pada lingkungan perairan. Fenol sebagai polutan yang terbuang ke lingkungan perairan ini sebagian besar tidak dapat diuraikan secara biologis, sehingga diperlukan penanganan khusus dalam mengatasinya. Pemisahan fenol menggunakan membran PIM (Polymer Inclusion Membrane) merupakan salah satu metode alternatif yang beberapa tahun terakhir menarik perhatian peneliti sebagai metode ramah lingkungan yang mendukung green chemistry. Hal ini dikarenakan tidak menggunakan jumlah pelarut dalam jumlah besar dan hanya menggunakan carrier dalam jumlah relatif sedikit (Sun et al., 2017). Penggunaan membran PIM untuk proses pemisahan telah banyak dilakukan oleh peneliti, baik untuk pemisahan logam-logam berat (Almeida et al., 2012; Bonggotgetsakul et al., 2016; Kaya et al., 2016; 
O’Bryan et al., 2017; Raut et al., 2012; Wang et al., 2017), maupun pemisahan senyawa-senyawa organik (Benosmane et al., 2018; Kiswandono et al., 2012; Ling and Suah, 2017).

Membran PIM menunjukkan kemampuan serbaguna dengan kestabilan yang sangat baik jika dibandingkan dengan teknologi membran cair lainnya. Kelebihan lainnya adalah membran PIM memiliki permukaan interfasial yang lebih luas, sangat selektif, kuat, mampu memisahkan senyawa secara efisien, dan proses pemisahan yang mudah (Ling and Suah, 2017). Senyawa pembawa yang terdapat dalam membran PIM mempengaruhi masa hidup membran (lifetime membrane) dalam memindahkan senyawa target ke fasa penerima. Dibandingkan dengan membran SLM (Supported Liquid Membrane), membran PIM memiliki masa hidup yang lebih lama. Hal ini dikarenakan mekanisme transpor membran PIM bergantung dari komposisi membran dan homogenitas permukaan membran. Hal ini menyebabkan membran PIM memiliki kelebihan dibandingkan membran SLM (Jean et al., 2018).

Proses transpor di dalam membran PIM membutuhkan suatu senyawa pembawa sebagai salah satu komponen pembentukan membran PIM. Berbagai cara untuk meningkatkan kestabilan dan permeabilitas membran tergantung dari polimer dasarnya atau dengan penambahan polimer taut silang (crosslinker) pada komposisi membran (Kiswandono et al., 2013). Keberadaan senyawa pembawa yang sesuai diharapkan mampu berinteraksi dengan senyawa target sehingga dapat membawa fenol dari fasa sumber ke fasa membran. Konsentrasi senyawa pembawa yang digunakan dalam teknologi membran umumnya jauh lebih kecil dibandingkan metode konvensional yang menggunakan pelarut lebih banyak. Kelebihan ini membuat membran PIM bersifat lebih ekonomis dengan pemakaian senyawa pembawa yang tepat sehingga selektivitas membran PIM menjadi lebih tinggi (Cho et al., 2018). Penggunaan co-EDVB sebagai senyawa pembawa telah dilakukan oleh Kiswandono et al. (2013) dengan konsentrasi co-EDVB 2\%, 6\%, dan 12\% untuk uji optimasi transpor fenol. Reaksi umum kopolieugenol divinil benzen (co-EDVB) dapat dilihat pada Gambar 1. Selanjutnya, untuk mengetahui efisiensi transpor pada konsentrasi co-EDVB yang lainnya belum dilakukan, maka penelitian ini melakukan sintesis kopoli-eugenol divinil benzen (co-EDVB) 10\% yang digunakan sebagai senyawa pembawa untuk memindahkan fenol dari fasa sumber ke fasa penerima menggunakan metode PIM.

\section{METODE PENELITIAN} Material

Alat-alat yang digunakan dalam penelitian ini meliputi satu set rangkaian alat transpor fenol (chamber atau pipa transpor kapasitas $40 \mathrm{~mL}$ dengan area sentuh antar chamber 2,5 cm dan stirrer), cetakan membran, neraca analitik digital (Mettler Toledo AB54-S), pH meter (HM-30R), thickness gauge (Mitutoyo 7301), spektrofotometer UV-Vis (Hitachi U-2010), Fourier Transform Infrared (FTIR) (Shimadzhu 820PC), Microwave Plasma-Atomic Emission Spectrometer (MP-AES), dan alat pengukur titik leleh (electrothermal 9100).

Bahan yang digunakan dalam penelitian ini adalah bahan kimia kualitas pro analis (pa) produksi Merck yaitu eugenol, $\mathrm{BF}_{3} \mathrm{O}\left(\mathrm{C}_{2} \mathrm{H}_{5}\right)_{2}$, divinil benzena (DVB), kloroform $\left(\mathrm{CHCl}_{3}\right)$, natrium sulfat anhidrat $\left(\mathrm{Na}_{2} \mathrm{SO}_{4}\right)$, dibenzil eter (DBE), tetrahidrofuran (THF), polivinil klorida ( $\mathrm{PVC})$, fenol $\left(\mathrm{C}_{6} \mathrm{H}_{5} \mathrm{OH}\right)$, natrium hidroksida $(\mathrm{NaOH})$, asam klorida $(\mathrm{HCl})$, 4-aminoantipirin, kalium ferrisianida $\left(\mathrm{K}_{4}\left[\mathrm{Fe}(\mathrm{CN})_{6}\right] \cdot 3 \mathrm{H}_{2} \mathrm{O}\right)$, ammonium hidroksida $\left(\mathrm{NH}_{4} \mathrm{OH}\right)$, buffer fosfat $\left(\mathrm{K}_{2} \mathrm{HPO}_{4}, \mathrm{KH}_{2} \mathrm{PO}_{4}\right)$, tembaga nitrat heksahidrat $\left[\mathrm{Cu}\left(\mathrm{NO}_{3}\right)_{2} \cdot 6 \mathrm{H}_{2} \mathrm{O}\right]$ dan timbal nitrat heksahidrat $\left[\mathrm{Pb}\left(\mathrm{NO}_{3}\right)_{2} \cdot 6 \mathrm{H}_{2} \mathrm{O}\right]$.

\section{Sintesis Kopoli(Eugenol-DVB) $\mathbf{1 0 \%}$}

Eugenol 5,8 g (0,035 mol) dimasukkan ke dalam labu bundar $250 \mathrm{~mL}$ dan ditambahkan DVB sebagai agen penyambung silang sebanyak $10 \%$ dari massa eugenol $\left(4,45 \times 10^{-3} \mathrm{~mol}\right)$. Proses polimerisasi berlangsung dengan

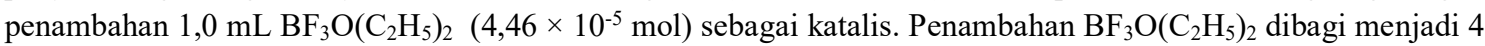
kali dengan selang waktu 1 jam. Reaksi polimerisasi terjadi ditandai dengan perubahan warna larutan menjadi ungu kemerahan. Reaksi polimerisasi dilakukan selama 24 jam pada suhu kamar dan dihentikan dengan menambahkan 1,0 mL metanol $\left(4,46 \times 10^{-5} \mathrm{~mol}\right)$. Gel merah yang terbentuk dilarutkan dalam kloroform dan dipindahkan ke dalam corong pisah kemudian dicuci dengan akuades hingga $\mathrm{pH}$ netral. Lapisan organik yang diperoleh ditambahkan $\mathrm{Na}_{2} \mathrm{SO}_{4}$ anhidrat kemudian didekantasi. Pelarutnya diuapkan melalui proses evaporasi pada suhu $40{ }^{\circ} \mathrm{C}$ dan residu disimpan dalam desikator. Padatan polimer yang terbentuk ditentukan titik lelehnya dan kemudian dikarakterisasi menggunakan Fourier Transform Infrared (FTIR).

\section{Pembuatan Membran PIM}

Membran PIM dibuat dari tiga komponen utama, yaitu PVC sebagai polimer dasar, senyawa pembawa co- 
EDVB 10\%, dan DBE sebagai plasticizer. Membran PIM dibuat pada suatu cetakan yang telah dilengkapi dengan magnetic stirrer. Total berat komponen penyususun membran adalah 0,270 g. Perbandingan massa co-EDVB sebagai seyawa pembawa, PVC sebagai polimer dasar, dan DBE sebagai plasticizer adalah 10:32:58. Tetrahidrofuran (THF) sebanyak $10 \mathrm{~mL}$ digunakan pada setiap pembuatan membran PIM yang berfungsi untuk menghomogenkan campuran dalam cetakan, kemudian hasil cetakan didiamkan selama tiga hari untuk menguapkan pelarut secara alami.

- Tahap Inisiasi

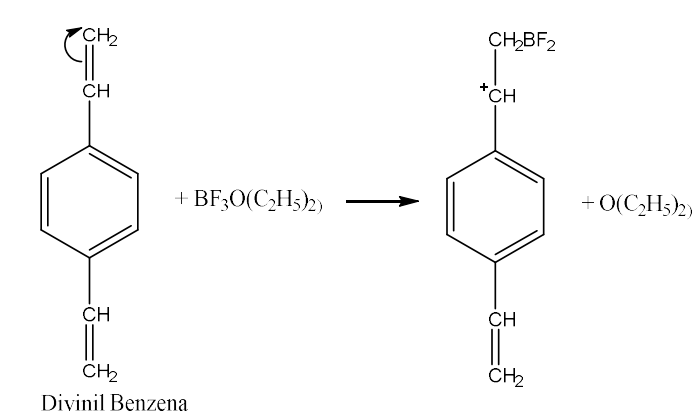

- Tahap Propagasi

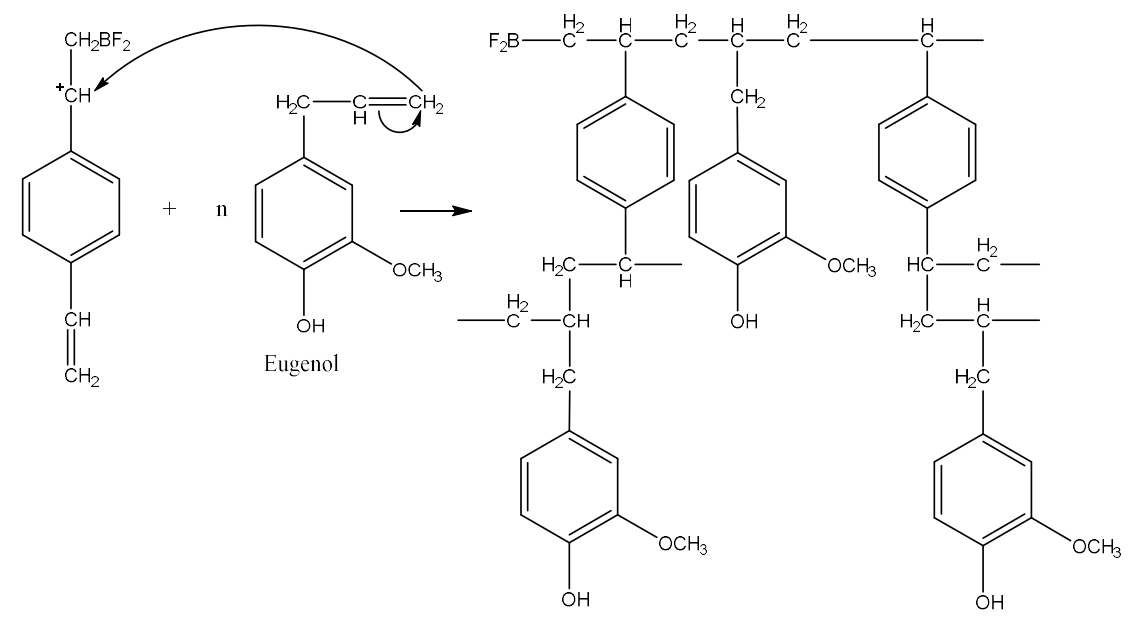

- Tahap Terminasi
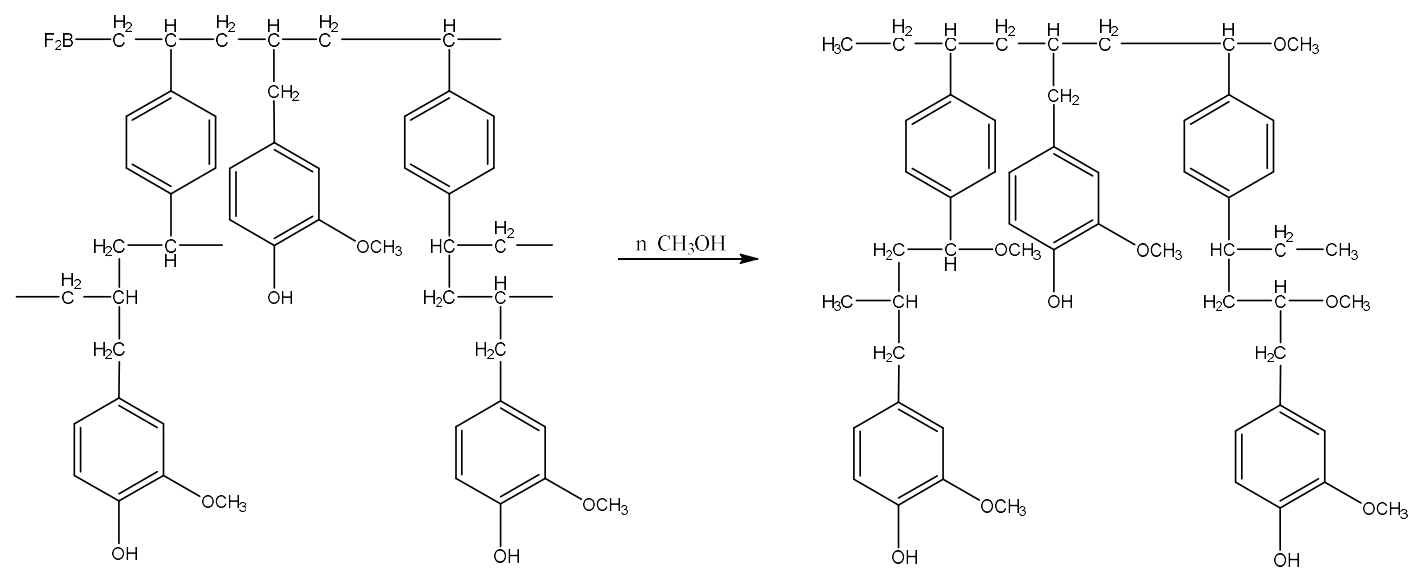

Kopoli(eugenol-DVB)

Gambar 1. Mekanisme reaksi sintesis kopoli (eugenol-DVB) (Handayani et al., 2004). 


\section{Transpor Fenol dan Uji Kompetisi dengan Logam Cu(II) dan Pb(II)}

Prosedur dan proses transpor fenol yang dilakukan pada penelitian ini mengikuti metode transpor yang telah dilakukan oleh Kiswandono et al. (2013). Alat transpor berupa dua gelas silinder (chamber) yang dipisahkan oleh membran (Gambar 2). Setiap chamber berisi $50 \mathrm{~mL}$ larutan fenol di fasa sumber dan $50 \mathrm{~mL}$ larutan $\mathrm{NaOH} 0,5 \mathrm{M}$ di fasa penerima, kemudian masing-masing larutan diaduk sesuai dengan prosedur, yakni ketebalan membran. Selanjutnya, untuk uji kompetisi, sampel limbah cair buatan yang mengandung fenol, $\mathrm{Cu}$ (II) dan $\mathrm{Pb}$ (II) dibuat dengan konsentrasi masing-masing 60 ppm. Penyediaan larutan sampel yaitu dengan mencampurkan $60 \mathrm{mg}$ fenol, $0,00959 \mathrm{~g} \mathrm{~Pb}\left(\mathrm{NO}_{3}\right)_{2}$ dan $0,0228 \mathrm{~g} \mathrm{Cu}\left(\mathrm{NO}_{3}\right)_{2} \cdot 3 \mathrm{H}_{2} \mathrm{O}$ dalam $100 \mathrm{~mL}$ larutan, kemudian dihomogenkan. Selanjutnya dilakukan transpor menggunakan membran PIM dengan ketebalan 0,10 mm. Membran ditempatkan di tengahtengah pipa transpor. Kemudian dimasukkan $50 \mathrm{~mL}$ limbah buatan sebagai fasa sumber dan $50 \mathrm{~mL} \mathrm{NaOH}$ sebagai fasa penerima dengan kondisi optimum. Setelah itu, pipa transpor ditutup dan diaduk dengan pengaduk magnet pada fasa sumber dan fasa penerima selama waktu optimum pada suhu kamar. Setelah selesai diaduk, diambil sampel fasa sumber dan fasa penerima. Konsentrasi fenol di dalam fasa sumber dan fasa penerima diukur menggunakan spektrofotometer $\mathrm{UV}$-Vis. Konsentrasi $\mathrm{Cu}$ dan $\mathrm{Pb}$ yang terdapat di dalam fasa penerima ditentukan menggunakan Microwave Plasma-Atomic Emission Spectrometer (MP-AES). Membran PIM sebelum dan sesudah transpor kemudian dikarakterisasi menggunakan Transform Infrared (FTIR).

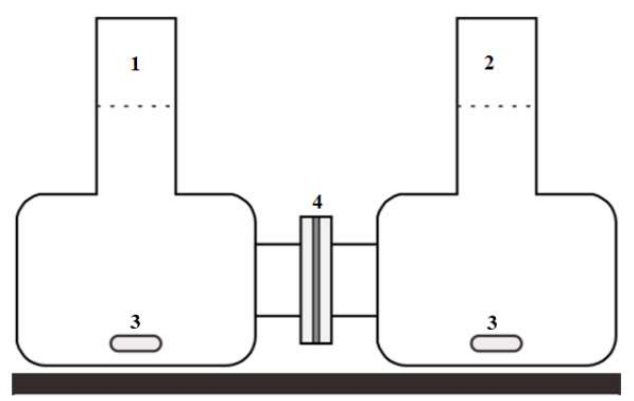

Gambar 2. Set alat transpor. 1 Fase sumber; 2 Fase penerima; 3 Magnetic stirrer; 4 Membran PIM (Kiswandono et al., 2012)

\section{HASIL DAN PEMBAHASAN}

\section{Sintesis Kopoli (Eugenol-DVB) $\mathbf{1 0} \%$}

Sintesis kopoli(eugenol-DVB) dalam penelitian ini menggunakan bahan dasar berupa eugenol, divinil benzena dan $\mathrm{BF}_{3} \mathrm{O}\left(\mathrm{C}_{2} \mathrm{H}_{5}\right)_{2}$ sebagai katalis. Reaksi pembentukan polimer ditandai dengan pembentukan gel berwarna ungu kemerahan pada saat katalis ditambahkan. Penambahan katalis dilakukan sebanyak empat kali secara bertahap setiap 1,5 jam (0,25 mL setiap penambahan). Secara fisik polimer yang dihasilkan berupa serbuk berwarna coklat muda. Reaksi kopolimerisasi ini dilakukan dengan menggunakan massa DVB 10\% terhadap berat eugenol. Kopolimerisasi ini merupakan reaksi kopolimerisasi adisi kationik, karena gugus vinil dari DVB mengalami adisi.

Tabel 1. Perbandingan gugus fungsi hasil FTIR eugenol dengan kopoli(eugenol-DVB) $10 \%$.

\begin{tabular}{lcc}
\hline Bilangan Gelombang $\left(\mathbf{c m}^{-\mathbf{1}}\right)$ & Kopoli(eugenol-DVB) & Gugus Fungsi \\
\hline Eugenol & 834,9 & Aromatis tersubstitusi \\
917,82 & Hilang & C-H Vinil \\
103,27 & 1028,7 & Regangan gugus eter $(-\mathrm{C}-\mathrm{O}-\mathrm{C}-$-) \\
1604,77 & 1602,8 & Regangan gugus C=C aromatik \\
1636,5 & Hilang & Regangan gugus alil $(\mathrm{C}=\mathrm{C})$ \\
2908,65 & 2929,7 & Regangan Csp ${ }^{3}-\mathrm{H}$ \\
3070,68 & Hilang & Regangan Csp ${ }^{2}-\mathrm{H}$ \\
3448,72 & 3526,1 & Regangan gugus $-\mathrm{OH}$ \\
\hline
\end{tabular}


Reaksi kopolimerisasi ini terjadi melalui 3 tahap (Gambar 1), yaitu tahap inisiasi, propagasi, dan terminasi. Tahap inisiasi merupakan tahap terjadinya pembentukan ion karbokation dari DVB. Penambahan katalis $\mathrm{BF}_{3} \mathrm{O}\left(\mathrm{C}_{2} \mathrm{H}_{5}\right)_{2}$ secara bertahap agar proses pembentukan ion karbokation terjadi secara berkelanjutan. Tahap propagasi merupakan tahap dimana ion karbokation akan berikatan dengan eugenol membentuk kopoli(eugenolDVB). Terakhir, tahap terminasi merupakan tahap dimana pemutusan pertumbuhan rantai polimer kopoli(eugenolDVB) dengan cara penambahan metanol. Serbuk kopoli(eugenol-DVB) 10\% yang sudah terbentuk selanjutnya dianalisis menggunakan FTIR. Hasil karakterisasi ini dapat dilihat pada Gambar 3. Perbandingan gugus fungsi hasil FTIR antara eugenol dan kopoli(eugenol-DVB) 10\% dalam penelitian ini dapat dilihat pada Tabel 1.

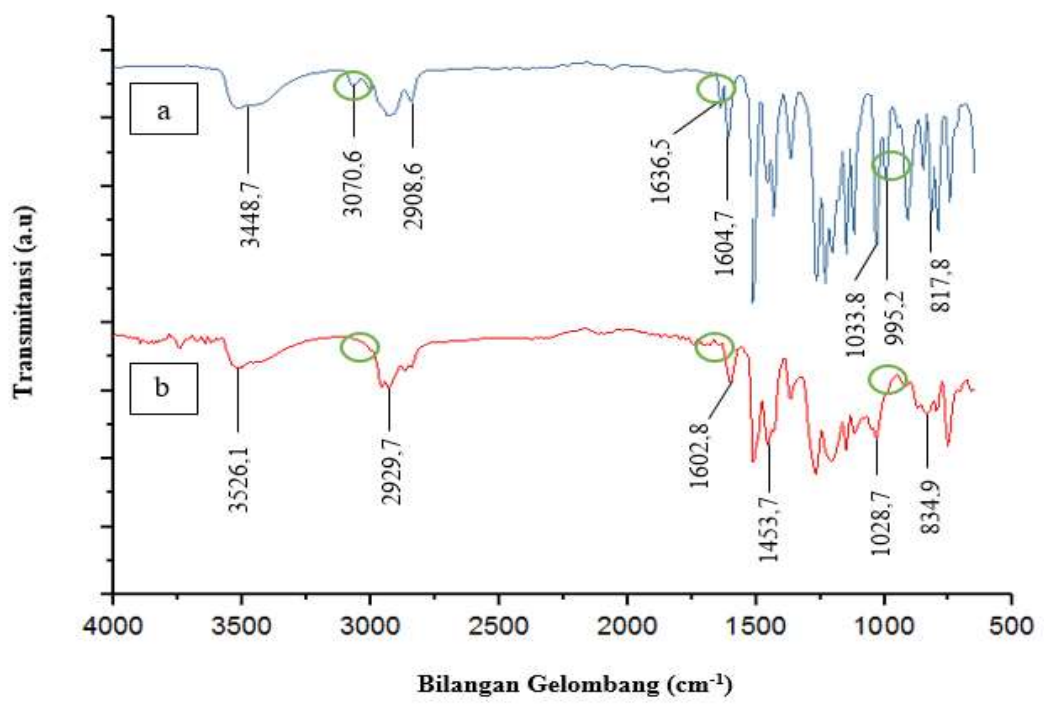

Gambar 3. Spektra FTIR dari (a) eugenol dan (b) kopoli(eugenol-DVB) 10\%.

Gambar 3 menunjukkan perbedaan hasil FTIR antara eugenol dan kopoli(eugenol DVB) 10\%. Senyawa eugenol memiliki gugus-gugus yang khas yaitu senyawa aromatis tersubstitusi 1, 2, 4 yang ditunjukkan oleh pita serapan pada bilangan gelombang $817,82 \mathrm{~cm}^{-1}$. Serapan pada bilangan gelombang $995,27 \mathrm{~cm}^{-1}$ menunjukkan ikatan $\mathrm{C}-\mathrm{H}$ gugus tak jenuh vinil $\left(\mathrm{CH}=\mathrm{CH}_{2}\right)$, pita serapan $1033,85 \mathrm{~cm}^{-1}$ menunjukkan adanya regangan gugus eter $\left(-\mathrm{C}-\mathrm{O}-\mathrm{C}-\right.$ ) dan serapan pada $3448,72 \mathrm{~cm}^{-1}$ menunjukkan adanya gugus $-\mathrm{OH}$. Selain itu terdapat serapan pada $1636,5 \mathrm{~cm}^{-1}$ yang menunjukkan regangan gugus alil untuk $\mathrm{C}=\mathrm{C}$ dan regangan $\mathrm{Csp}^{3}-\mathrm{H}$ pada bilangan gelombang $2908,65 \mathrm{~cm}^{-1}$.

Perbedaan yang jelas antara hasil FTIR eugenol dan kopoli(eugenol-DVB) 10\% menunjukkan polimerisasi kopoli(eugenol-DVB) 10\% telah berhasil dilakukan. Pembentukan kopoli(eugenol-DVB) 10\% ditandai dengan hilangnya serapan regangan gugus alil $\mathrm{C}=\mathrm{C}\left(1636,5 \mathrm{~cm}^{-1}\right)$, ikatan $\mathrm{C}-\mathrm{H}$ vinil $\left(-\mathrm{CH}=\mathrm{CH}_{2}\right)\left(995,27 \mathrm{~cm}^{-1}\right)$ dan regangan $\mathrm{Csp}^{2}-\mathrm{H}$ pada serapan $3070,68 \mathrm{~cm}^{-1}$. Selain itu masih terdapat serapan pada $2929,7 \mathrm{~cm}^{-1} \mathrm{yang}$ menunjukkan adanya regangan $\mathrm{Csp}^{3}-\mathrm{H}$ dan adanya regangan gugus $-\mathrm{OH}$ ditunjukkan pada serapan $3526,1 \mathrm{~cm}^{-1}$. Regangan gugus $\mathrm{C}=\mathrm{C}$ aromatik pada benzena ditunjukkan pada serapan $1602,8 \mathrm{~cm}^{-1}$ yang diperkuat dengan serapan $1453,7 \mathrm{~cm}^{-1}$ dan gugus $\left(-\mathrm{C}-\mathrm{O}-\mathrm{C}-\right.$ ) eter pada bilangan gelombang $1028,7 \mathrm{~cm}^{-1}$. Selain dikarakterisasi menggunakan FTIR, pada sintesis kopoli(eugenol-DVB) 10\% juga dilakukan pengujian titik leleh terhadap serbuk kopoli(eugenol-DVB). Hasil pengujian titik leleh polimer ini dapat dilihat pada Tabel 2.

Tabel 2. Titik leleh hasil sintesis kopoli(eugenol-DVB).

\begin{tabular}{lcc}
\hline Sampel & Titik Leleh $\left({ }^{\circ} \mathbf{C}\right)$ & Referensi \\
\hline Kopoli(eugenol-DVB) $2 \%$ & $88,4-95,7$ & Kiswandono et al. $(2013)$ \\
Kopoli(eugenol-DVB) $6 \%$ & $89,0-102$ & Kiswandono et al. $(2013)$ \\
Kopoli(eugenol-DVB) $10 \%$ & $99,5-107,6$ & Penelitian ini \\
Kopoli(eugenol-DVB) $12 \%$ & $100,6-109,0$ & Kiswandono et al. $(2013)$ \\
\hline
\end{tabular}

Tabel 2 menunjukkan pengaruh komposisi kopoli(eugenol-DVB) 10\% terhadap titik leleh. Semakin banyak jumlah DVB yang ditambahkan maka akan semakin meningkatkan titik leleh dari kopoli(eugenol-DVB) yang dihasilkan. Titik leleh kopoli(eugenol-DVB) meningkat seiring dengan meningkatnya jumlah mol monomer 
(DVB) yang ditambahkan. Hal ini dapat diasumsikan bahwa rantai polimer bertambah panjang dengan bertambahnya DVB yang akan mempengaruhi berat molekul dari kopoli(eugenol-DVB). Peningkatan jumlah berat molekul secara teori akan meningkatkan titik leleh suatu senyawa.

\section{Pembuatan Membran PIM}

Membran PIM disusun atas 3 komponen yaitu senyawa pembawa, polimer dasar (pendukung) dan plasticizer. Senyawa carrier berfungsi memfasilitasi senyawa target untuk dapat tertranspor ke fasa penerima melewati pori membran. Polimer dasar (pendukung) berfungsi untuk menahan kebocoran senyawa carrier pada membran. Plasticizer berfungsi untuk membuat sistem di dalam membran menjadi lebih stabil terhadap kebocoran. Pada penelitian ini senyawa carrier yang digunakan adalah kopoli(eugenol-DVB) 10\%, PVC sebagai polimer dasar dan DBE sebagai plasticizer. Membran PIM dibuat dengan 3 variasi berat total komponen penyusunnya $\left(\mathrm{T}_{27}, \mathrm{~T}_{54} \mathrm{dan}\right.$ $\mathrm{T}_{108}$ ) yaitu 0,$27 ; 0,54$ dan 1,08 g. Variasi berat total komponen penyusun membran akan menghasilkan membran dengan ketebalan yang berbeda-beda. Membran PIM yang telah selesai dibuat, diukur ketebalannya menggunakan thickness gauge. Ketebalan membran PIM yang dihasilkan dapat dilihat pada Tabel 3.

Tabel 3. Ketebalan membran PIM.

\begin{tabular}{lcc}
\hline Tipe Membran & Berat Total Komponen (g) & Ketebalan Membran (mm) \\
\hline $\mathrm{T}_{27}$ & 0,27 & 0,10 \\
$\mathrm{~T}_{54}$ & 0,54 & 0,26 \\
$\mathrm{~T}_{108}$ & 1,08 & 0,52 \\
\hline
\end{tabular}

\section{Efek Ketebalan Membran PIM}

Ketebalan membran PIM yang digunakan berpengaruh terhadap berlangsungnya transpor fenol. Variasi berat dari komponen-komponen pembentuk membran akan menyebabkan perbedaan ketebalan membran yang dihasilkan. Variasi ketebalan membran PIM yang digunakan pada penelitian ini yaitu membran tipe $\mathrm{T}_{27}, \mathrm{~T}_{54}$ dan $\mathrm{T}_{108}$. Membran $\mathrm{T}_{27}$ adalah membran dengan berat total komponen 0,27 $\mathrm{g}$ dan memiliki ketebalan sebesar 0,10 mm. Membran $\mathrm{T}_{54}$ adalah membran dengan berat total komponen $0,54 \mathrm{~g}$ dan memiliki ketebalan sebesar 0,26 mm. Membran $\mathrm{T}_{108}$ adalah membran dengan berat total komponen 1,08 g dan memiliki ketebalan sebesar 0,52 mm. Hasil penelitian mengenai pengaruh ketebalan membran terhadap transpor fenol, dapat dilihat pada Gambar 4.

Hasil penelitian pada Gambar 4 menunjukkan membran tipe $\mathrm{T}_{54}$ dan $\mathrm{T}_{108}$ menghasilkan konsentrasi fenol yang tertranspor lebih rendah dibandingkan pada membran $\mathrm{T}_{27}$. Konsentrasi fenol yang tertranspor pada membran $\mathrm{T}_{54}$ dan $\mathrm{T}_{108}$ yaitu sebesar $41,80 \%$ dan $36,00 \%$. Hal ini dikarenakan membran $\mathrm{T}_{54}$ dan $\mathrm{T}_{108}$ memiliki ketebalan dan kandungan plasticizer yang lebih besar dibandingkan membran $\mathrm{T}_{27}$. Plasticizer pada membran dibutuhkan agar membran yang terbetuk elastis dan tidak kaku. Selain itu, plasticizer juga dapat memadatkan membran pada proses pencetakannya. Jumlah plasticizer yang besar menyebabkan pori-pori membran tertutupi, sehingga memberikan halangan terhadap fenol untuk berdifusi melewati membran. Terhalangnya fenol untuk berdifusi menyebabkan interaksi antara fenol dengan senyawa carrier pada membran menjadi berkurang. Akibatnya fenol yang tertranspor ke fasa penerima menjadi semakin rendah. Menurut Gardner et al. (2006), semakin banyak plasticizer yang digunakan akan meningkatkan viskositas dari membran. Transpor fenol akan menurun seiring dengan meningkatnya viskositas membran.

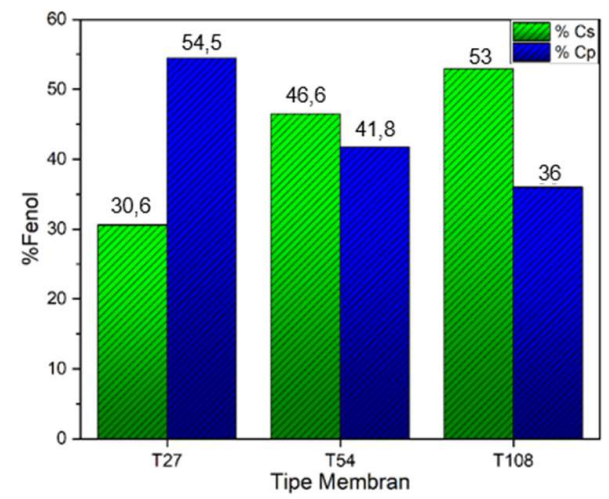

Gambar 4. Pengaruh ketebalan membran Kopoli(Eugenol-DVB) 10\% terhadap konsentrasi fenol yang tertranspor. 


\section{Uji Kompetisi Transpor Fenol dengan Logam $\mathrm{Cu}(\mathrm{II})$ dan $\mathrm{Pb}(\mathrm{II})$}

Studi kompetisi transpor fenol dilakukan untuk mengetahui pengaruh adanya logam terhadap konsentrasi fenol yang tertranspor ke fasa penerima. Tujuan dari studi ini untuk mengetahui selektivitas membran PIM dalam mentranspor fenol. Pada penelitian ini dilakukan transpor fenol dalam sampel limbah cair buatan yang mengandung $\mathrm{Cu}$ (II) dan $\mathrm{Pb}(\mathrm{II})$. Logam $\mathrm{Cu}$ (II) dan $\mathrm{Pb}$ (II) diasumsikan sebagai logam yang terdapat pada limbah cair. Limbah cair buatan dibuat dengan mencampurkan fenol, $\mathrm{Cu}$ (II) dan $\mathrm{Pb}$ (II) dengan konsentrasi masing-masing $60 \mathrm{ppm}$ dalam $100 \mathrm{~mL}$ larutan. Transpor fenol dilakukan selama 9 jam menggunakan membran PIM dengan senyawa carrier kopoli(eugenol-DVB) 10\%. Hasil penelitian mengenai pengaruh adanya logam kompetitor $\mathrm{Cu}(\mathrm{II})$ dan $\mathrm{Pb}(\mathrm{II})$ terhadap transpor fenol, dapat dilihat pada Gambar 5.

Gambar 5 menunjukan bahwa konsentrasi fenol, logam $\mathrm{Cu}$ (II) dan $\mathrm{Pb}$ (II) yang berhasil tertranspor ke fasa penerima. Konsentrasi fenol yang tertranspor ke fasa penerima sebesar 27,25\% atau setara dengan 16,35 ppm. Konsentrasi logam $\mathrm{Cu}(\mathrm{II})$ yang terdeteksi pada fasa penerima sebesar 0,12\% atau setara dengan $0,07 \mathrm{ppm}$. Konsentrasi logam $\mathrm{Pb}$ (II) yang terdeteksi pada fasa penerima sebesar 0,40\% atau setara dengan 0,24 ppm. Konsentrasi logam yang tertranspor ke fasa penerima tidak menunjukkan jumlah yang signifikan atau dapat dikatakan hampir tidak tertranspor. Hasil ini menunjukkan bahwa transpor fenol menggunakan metode PIM dengan senyawa carrier kopoli(eugenol-DVB) 10\% merupakan metode yang cukup selektif untuk recovery fenol dalam limbah cair yang mengandung logam $\mathrm{Pb}(\mathrm{II})$ dan $\mathrm{Cu}(\mathrm{II})$. Hal ini dibuktikan dengan konsentrasi fenol yang tertranspor ke fasa penerima jauh lebih besar dari logam kompetitor yaitu sebesar 27,25\%.

Pengaruh adanya logam kompetitor terhadap transpor fenol memberikan hasil transpor yang lebih rendah bila dibandingkan dengan transpor fenol tanpa adanya logam kompetitor. Perbandingan hasil transpor fenol dengan dan tanpa logam kompetitor dapat dilihat pada Gambar 5a.
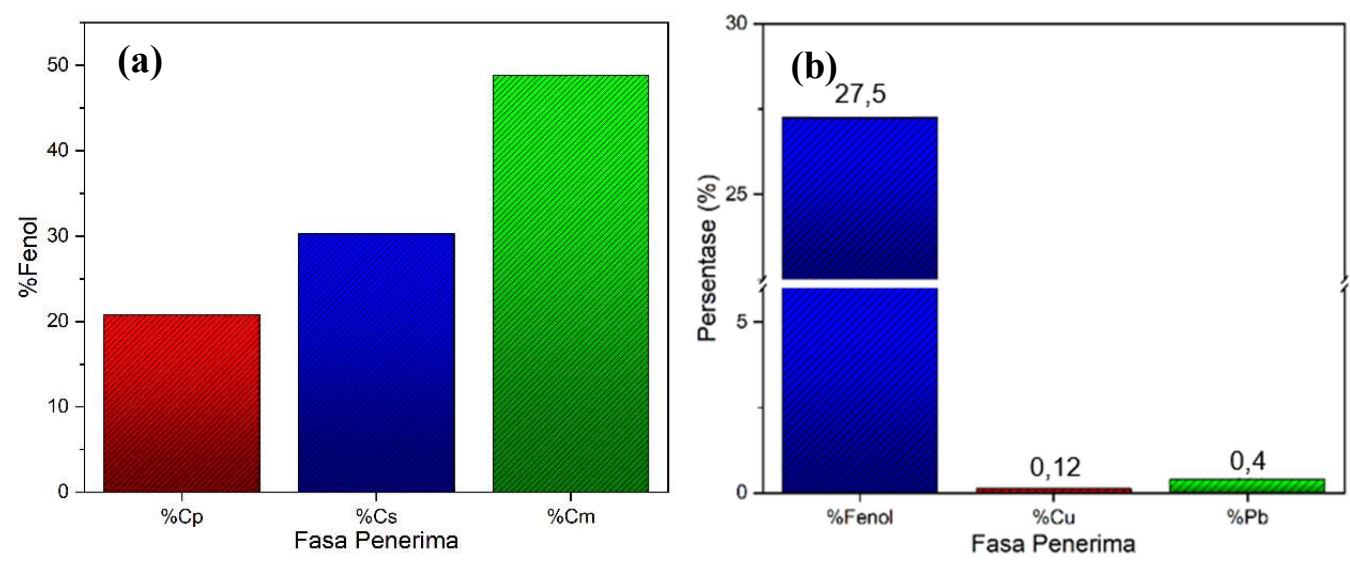

Gambar 5. Perbandingan konsentrasi fenol yang tertranspor ke fasa penerima (a) transpor fenol tanpa logam kompetitor dan (b) transpor fenol dengan logam kompetitor.

Gambar 5a menunjukkan konsentrasi fenol yang tertranspor ke fasa penerima tanpa logam kompetitor adalah sebesar 48,80\%. Sedangkan pada Gambar 5b menunjukkan konsentrasi fenol yang tertranspor ke fasa penerima yaitu sebesar 27,25\%. Konsentrasi fenol yang tertranspor menurun secara signifikan dengan adanya logam kompetitor. Hal ini mengindikasikan bahwa keberadaan logam dalam sampel mengganggu proses berlangsungnya transpor fenol ke fasa penerima meskipun jumlah logam yang tertranspor sangat kecil. Gangguan dari logam kompetitor terhadap transpor fenol dapat berupa interaksi antara logam dan sisi aktif senyawa carrier pada membran. Kemungkinan interaksi antara logam dengan senyawa carrier pada membran akan membentuk suatu senyawa kompleks. Perkiraan interaksi yang terjadi antara senyawa carrier dengan logam kompetitor dapat dilihat pada Gambar 6. 


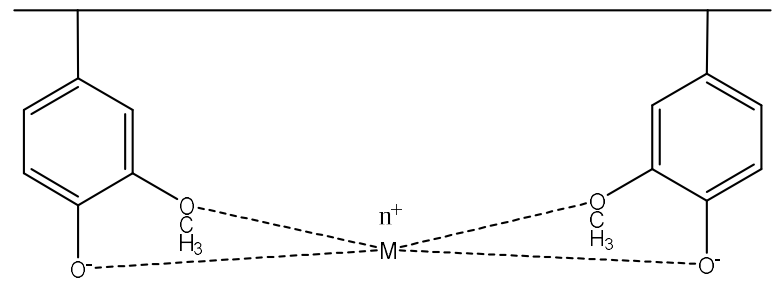

Gambar 6. Perkiraan bentuk kompleks pengemban ion kopoli(eugenol-DVB) dengan ion logam $\mathrm{M}$ ( $\mathrm{Pb}(\mathrm{II}) \mathrm{dan}$ $\mathrm{Cu}(\mathrm{II})$ ) (Harimu et al., 2010).

Reaksi pengompleksan dapat terjadi pada logam $\mathrm{Cu}(\mathrm{II})$ dan $\mathrm{Pb}$ (II) dalam bentuk tetrahedral saat transpor menggunakan metode membran cair. Hal ini dapat terjadi karena kecenderungan adanya protonasi senyawa carrier pada membran ketika bersentuhan dengan fasa sumber yang memiliki $\mathrm{pH}$ rendah. Keberadaan logam mengakibatkan adanya kompetisi kation logam terhadap $\mathrm{H}^{+}$untuk membentuk ikatan kovalen koordinasi dengan senyawa carrier sebagai pengemban ion pada membran (Harimu et al., 2010).

\section{KESIMPULAN}

Berdasarkan hasil FTIR, telah berhasil disintesis senyawa kopoli(eugenol-DVB) $10 \%$. Senyawa tersebut dapat digunakan sebagai senyawa pembawa pada proses transpor fenol menggunakan metode Polymer Inclusion Membrane (PIM). Hasil transpor logam $\mathrm{Cu}(\mathrm{II})$ dan $\mathrm{Pb}$ (II) pada kompetisi transpor fenol berturut-turut sebesar $0,12 \%$ dan $0,40 \%$, sehingga hasil yang tidak signifikan ini menunjukkan bahwa membran PIM dengan senyawa carrier kopoli(eugenol-DVB) 10\% memiliki selektivitas yang cukup baik dalam transpor fenol.

\section{UCAPAN TERIMA KASIH}

Tim peneliti mengucapkan terima kasih kepada LPPM Universitas Lampung dimana kegiatan ini dibiayai oleh Dana DIPA BLU UNILA tahun 2020 dengan nomor kontrak: 1503/UN26.21/PN/2020 Tanggal 24 Maret 2020 .

\section{DAFTAR PUSTAKA}

Almeida, M.I.G.S., Cattrall, R.W., and Kolev, S.D., 2012. Recent Trends in Extraction and Transport of Metal Ions Using Polymer Inclusion Membranes (PIMs). Journal of Membrane Science, 415-416, 9-23. doi: 10.1016/j.memsci.2012.06.006.

Benosmane, N., Boutemeur, B., Hamdi, S.M., and Hamdi, M., 2018. Removal of Phenol from Aqueous Solution Using Polymer Inclusion Membrane Based on Mixture of CTA and CA. Applied Water Science, 8, 17. doi: 10.1007/s13201-018-0643-8.

Bonggotgetsakul, Y.Y.N., Cattrall, R.W., and Kolev, S.D., 2016. Recovery of Gold from Aqua Regia Digested Electronic Scrap Using a Poly(Vinylidene Fluoride-Co-Hexafluoropropene) (PVDF-HFP) Based Polymer Inclusion Membrane (PIM) Containing Cyphos ${ }^{\circledR}$ IL 104. Journal of Membrane Science, 514, 274-281. doi: 10.1016/j.memsci.2016.05.002.

Cho, Y., Cattrall, R.W., and Kolev, S.D., 2018. A Novel Polymer Inclusion Membrane Based Method for Continuous Clean-up of Thiocyanate from Gold Mine Tailings Water. Journal of Hazardous Materials, 341, 297-303. doi: 10.1016/j.jhazmat.2017.07.069.

Gardner, J.S., Peterson, Q.P., Walker, J.O., Jensen, B.D., Adhikary, B., Harrison, R.G., and Lamb, J.D., 2006. Anion Transport through Polymer Inclusion Membranes Facilitated by Transition Metal Containing Carriers. Journal of Membrane Science, 277, 165-176. doi: 10.1016/j.memsci.2005.10.026.

Handayani, D.S., Kusumaningsih, T., and Yuli, M., 2004. Synthesis of Co-Poly(Eugenol Sulfonate)-DVB from Eugenol as a Major Component of Syzygium Aromaticum Oils. Biofarmasi Journal of Natural Product Biochemistry, 2, 53-57. doi: 10.13057/biofar/f020202.

Harimu, L., Matsjeh, S., Siswanta, D., and Santosa, S.J., 2010. Pemisahan Ion Logam Berat Fe(III), Cr(III), Cu(II), $\mathrm{Hi}(\mathrm{II}), \mathrm{Co}(\mathrm{II})$, Dan Pb(II) Menggunakan Pengemban Ion Poli (Asam Eugenil Oksiasetat) Dengan Metode Transpor Membran Cair. Indonesian Journal of Chemistry, 10, 69-74.

Jean, E., Villemin, D., Hlaibi, M., and Lebrun, L., 2018. Heavy Metal Ions Extraction Using New Supported Liquid Membranes Containing Ionic Liquid as Carrier. Separation and Purification Technology, 201, 1-9. doi: 10.1016/j.seppur.2018.02.033.

Kaya, A., Onac, C., Alpoguz, H.K., Yilmaz, A., and Atar, N., 2016. Removal of Cr(VI) through Calixarene Based 
Polymer Inclusion Membrane from Chrome Plating Bath Water. Chemical Engineering Journal, 283, 141149. doi: 10.1016/j.cej.2015.07.052.

Kiswandono, A.A., Siswanta, D., Aprilita, N.H., and Santosa, S.J., 2012. Transport of Phenol through Inclusion Polymer Membrane (PIM) Using Copoly(Eugenol-DVB) as Membrane Carriers. Indonesian Journal of Chemistry, 12, 105-112. doi: 10.22146/ijc.21348.

Kiswandono, A.A., Siswanta, D., Aprilita, N.H., Santosa, S.J., and Hayashita, T., 2013. Extending The Life Time of Polymer Inclusion Membrane Containing Copoly(Eugenol-DVB) as Carrier for Phenol Transport. Indonesian Journal of Chemistry, 13, 254-261. doi: 10.22146/ijc.21285.

Ling, Y.Y., and Mohd Suah, F.B., 2017. Extraction of Malachite Green from Wastewater by Using Polymer Inclusion Membrane. Journal of Environmental Chemical Engineering, 5, 785-794. doi: 10.1016/j.jece.2017.01.001.

O’Bryan, Y., Truong, Y.B., Cattrall, R.W., Kyratzis, I.L., and Kolev, S.D., 2017. A New Generation of Highly Stable and Permeable Polymer Inclusion Membranes (PIMs) with Their Carrier Immobilized in a Crosslinked Semi-Interpenetrating Polymer Network. Application to the Transport of Thiocyanate. Journal of Membrane Science, 529, 55-62. doi: 10.1016/j.memsci.2017.01.057.

Raut, D.R., Kandwal, P., Rebello, G., and Mohapatra, P.K., 2012. Evaluation of Polymer Inclusion Membranes Containing Calix[4]-Bis-2,3-Naptho-Crown-6 for Cs Recovery from Acidic Feeds: Transport Behavior, Morphology and Modeling Studies. Journal of Membrane Science, 407-408, 17-26. doi: 10.1016/j.memsci.2012.02.050.

Suah, F.B.M., and Ahmad, M., 2017. Preparation and Characterization of Polymer Inclusion Membrane Based Optode for Determination of $\mathrm{Al}^{3+}$ ion. Analytica Chimica Acta, 951, 133-139. doi: 10.1016/j.aca.2016.11.040.

Sun, H., Yao, J., Cong, H., Li, Q., Li, D., and Liu, B., 2017. Enhancing the Stability of Supported Liquid Membrane in Phenols Removal Process by Hydrophobic Modification. Chemical Engineering Research and Design, 126, 209-216. doi: 10.1016/j.cherd.2017.08.027.

Wang, D., Hu, J., Liu, D., Chen, Q., and Li, J., 2017. Selective Transport and Simultaneous Separation of Cu(II), $\mathrm{Zn}(\mathrm{II})$ and $\mathrm{Mg}(\mathrm{II})$ Using a Dual Polymer Inclusion Membrane System. Journal of Membrane Science, 524, 205-213. doi: 10.1016/j.memsci.2016.11.027. 